\title{
Bipolar Switching Characteristics of RRAM Cells with $\mathrm{CaBi}_{4} \mathrm{Ti}_{4} \mathbf{O}_{15}$ Film
}

\author{
Jian-Yang Lin $^{1}$ and Chia-Lin $\mathrm{Wu}^{2}$ \\ ${ }^{1}$ Department of Electronic Engineering, National Yunlin University of Science and Technology, Douliou 64002, Taiwan \\ ${ }^{2}$ Graduate School of Engineering Science \& Technology, National Yunlin University of Science and Technology, \\ Douliou 64002, Taiwan
}

Correspondence should be addressed to Jian-Yang Lin; linjy@yuntech.edu.tw

Received 4 October 2013; Revised 28 November 2013; Accepted 15 December 2013; Published 2 January 2014

Academic Editor: Fu-Chien Chiu

Copyright (C) 2014 J.-Y. Lin and C.-L. Wu. This is an open access article distributed under the Creative Commons Attribution License, which permits unrestricted use, distribution, and reproduction in any medium, provided the original work is properly cited.

\begin{abstract}
The electrical conduction and bipolar switching properties of resistive random access memory (RRAM) cells with transparent calcium bismuth titanate $\left(\mathrm{CaBi}_{4} \mathrm{Ti}_{4} \mathrm{O}_{15}-\mathrm{CBTi144}\right)$ thin films were investigated. Experimentally, the (119)-oriented CBTil44 thin films were deposited onto the ITO/glass substrates by RF magnetron sputtering followed by rapid thermal annealing (RTA) at a temperature range of $450-550^{\circ} \mathrm{C}$. The surface morphologies and crystal structures of the CBTil44 thin films were examined by using field-emission scanning electron microscopy and X-ray diffraction measurements. The on/off ratio and switching behaviors of the transparent Al/CBTi144/ITO/glass RRAM devices were further discussed in this work.
\end{abstract}

\section{Introduction}

Recently, various new nonvolatile memory devices were investigated, such as ferroelectric random access memory (FeRAM), resistive random access memory (RRAM), and phase change memory (PCM). Especially, the RRAM that composed of a simple metal-insulator-metal (MIM) structure has the advantages of low power consumption, high speed operation, good retention, and high-density integration capability [1-3]. Recent RRAM research includes perovskite oxides and metal oxides with different electrodes such as VO [4], $\mathrm{Pr}_{0.7} \mathrm{Ca}_{0.3} \mathrm{MnO}_{3}$ [5], $\mathrm{NiO}$ [6], $\mathrm{La}_{2} \mathrm{O}_{3}$ [7], $\mathrm{Dy}_{2} \mathrm{O}_{3}$ [8], and $\mathrm{ZnO}[9]$.

Several perovskite materials, such as $\mathrm{SrBi}_{4} \mathrm{Ti}_{4} \mathrm{O}_{15}$ (SBT) [10], $\quad\left(\mathrm{Ba}_{0.7} \mathrm{Sr}_{0.3}\right)\left(\mathrm{Ti}_{0.9} \mathrm{Zr}_{0.1}\right) \mathrm{O}_{3} \quad$ [11], $\mathrm{CaBi}_{4} \mathrm{Ti}_{4} \mathrm{O}_{15}$ (CBT) [12, 13], $\mathrm{CaBi}_{4-x} \mathrm{Nd}_{x} \mathrm{Ti}_{4} \mathrm{O}_{15}(\mathrm{CBNT}) \quad[14]$, and $\mathrm{Ca}_{1-x} \mathrm{La}_{x} \mathrm{Bi}_{4}\left(\mathrm{Ti}_{0.9} \mathrm{~W}_{0.1}\right)_{4} \mathrm{O}_{15}$ (CLBTW) [15], have been developed and investigated recently. Especially, the CBT film has high Curie temperature and low current density $[16,17]$. In this study, we have investigated the bipolar resistive switching properties of the CBTil44 thin films in the metalinsulator-metal (MIM) structure for memory application.

\section{Experiment}

In this study, the CBTil44 thin films were deposited onto the ITO/glass substrates by RF magnetron sputtering with a ceramic CBTil44 target. Ceramic target of CBTil44 was prepared by conventional solid-state reaction technique. First, raw materials of $\mathrm{Bi}_{2} \mathrm{O}_{3}, \mathrm{CaO}$, and $\mathrm{TiO}_{2}$ were weighted first according to the stoichiometric ratio of $\mathrm{CaBi}_{4} \mathrm{Ti}_{4} \mathrm{O}_{15}$. After mixing of the raw materials, the mixed material was ball-milled for $5 \mathrm{~h}$. The mixture was then dried and calcined at $1100^{\circ} \mathrm{C}$ for $4 \mathrm{~h}$. Finally, the CBTil4 4 target was formed with a diameter of 2 inches. The CBTil 44 films of $300 \mathrm{~nm}$ thickness were then deposited onto the ITO/glass substrates by RF magnetron sputtering with the CBTil44 target. The preparation conditions of the CBTil44 thin films are summarized in Table 1. To form the transparent MIM Al/CBTi144/ITO/glass RRAM device structure as shown in Figure 1, the top $\mathrm{Al}$ electrodes were patterned using a metal mask and deposited on top of the CBTilu4 film by thermal evaporation. The phase and the surface morphology of the deposited CBTil44 films were characterized by X-ray diffraction (XRD) and field-emission scanning electron microscopy (FE-SEM). The 


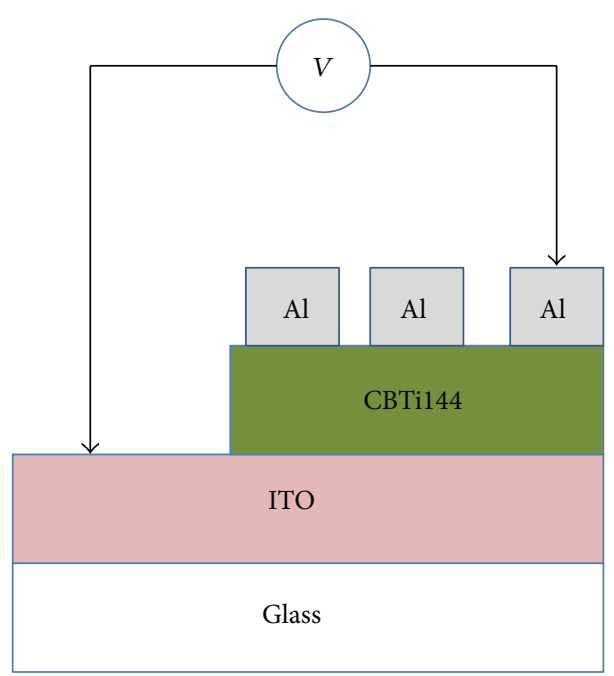

FIgURE 1: Metal-insulator-metal (MIM) capacitor structure of the CBTil44 RRAM device.

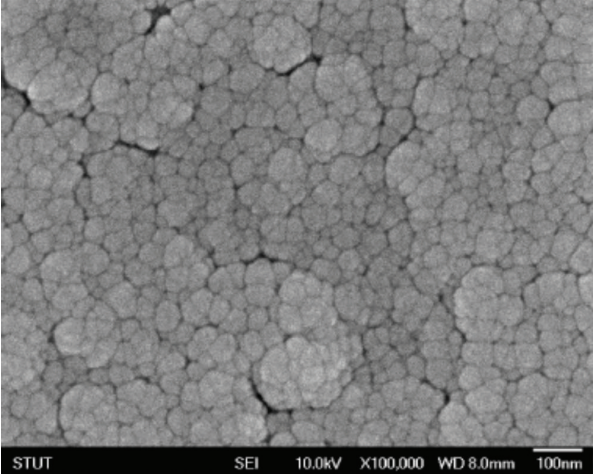

(a)

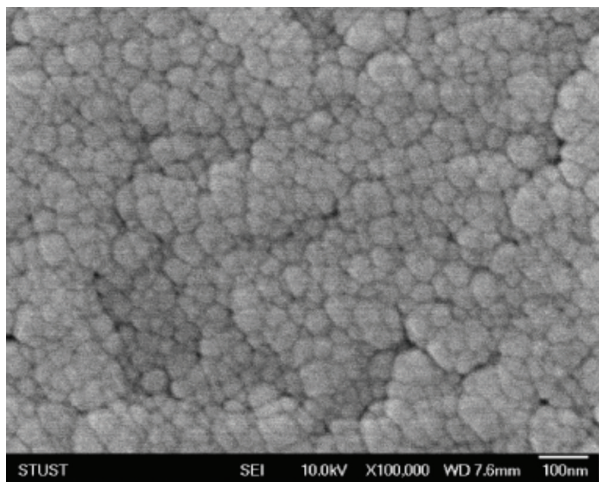

(c)

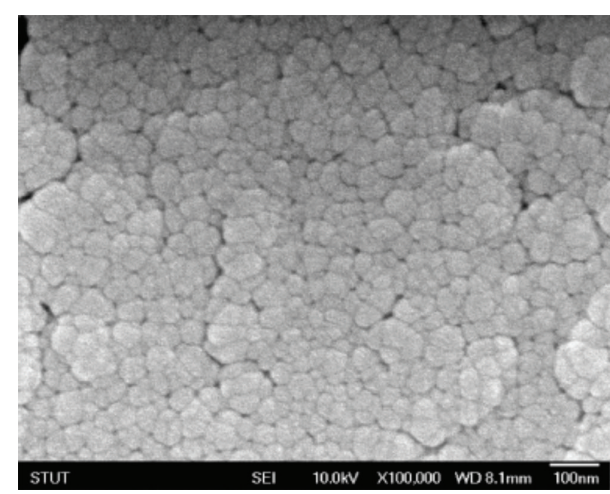

(b)

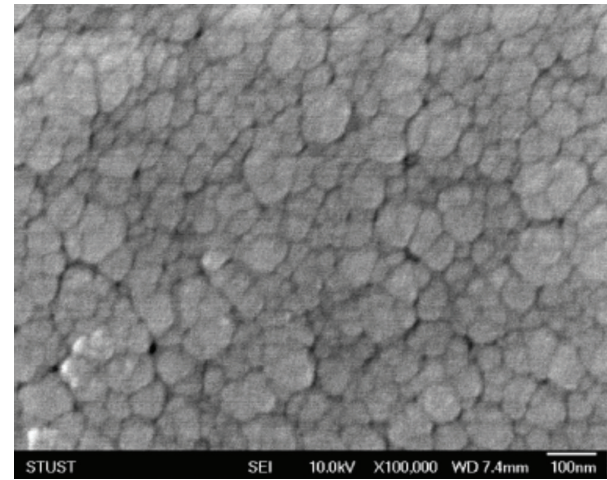

(d)

Figure 2: Surface morphologies of the CBTil44 films with (a) no annealing, (b) $450^{\circ} \mathrm{C}$ RTA, (c) $500^{\circ} \mathrm{C}$ RTA, and (d) $550^{\circ} \mathrm{C}$ RTA.

leakage current characteristics of the CBTi144 thin films were measured by a gain phase analyzer (HP4156C).

\section{Results and Discussion}

Figure 2 shows the FE-SEM micrographs of the CBTi144 thin films without annealing and with rapid thermal annealing (RTA) at 450,500 , and $550^{\circ} \mathrm{C}$. As the annealing temperature is increased, the grain size of the CBTil44 film slightly increases and the porosity of the CBTil44 film decreases because the oxygen vacancy concentration in the CBTil44 film decreases [18].

Figure 3 shows the XRD patterns of the CBTil44 thin films without and with $450-550^{\circ} \mathrm{C}$ RTA. The XRD patterns were used to identify the changes on crystalline structures of annealed CBT thin films. The results of the XRD analysis 


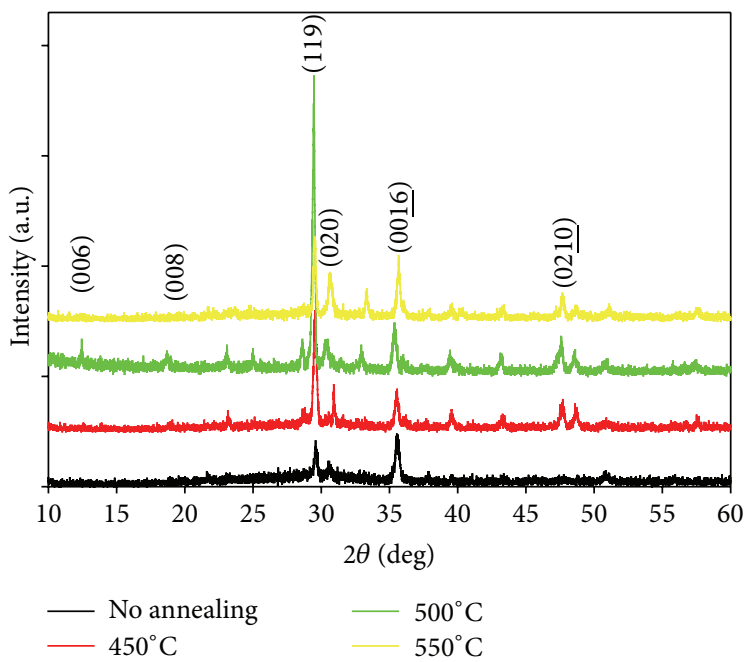

FIGURE 3: XRD patterns of the CBTil44 thin films with different annealing temperatures.

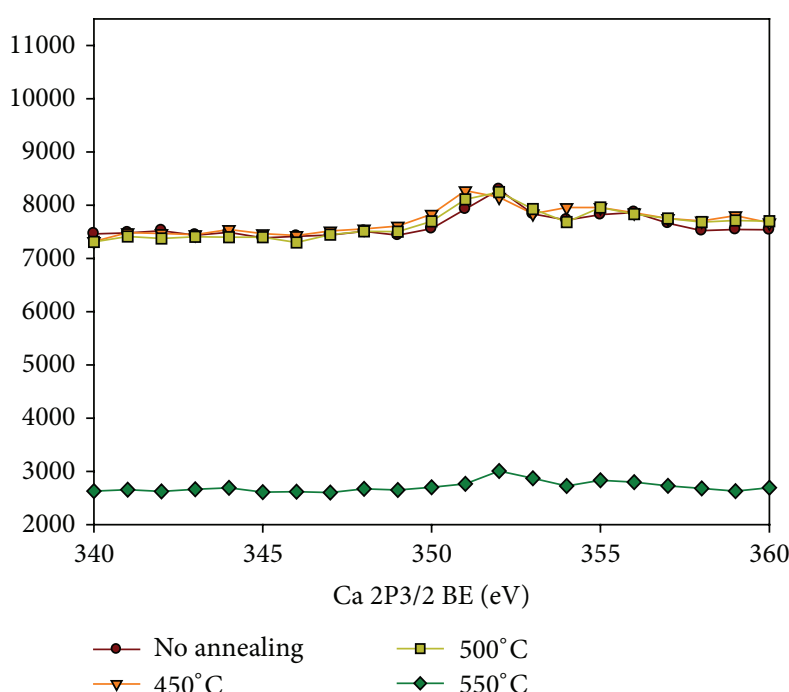

(a)

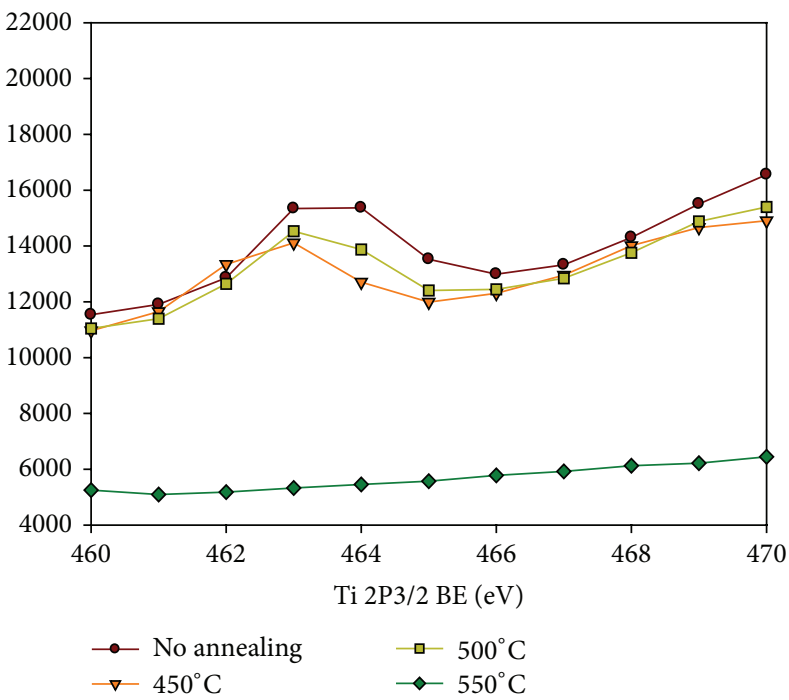

(c)

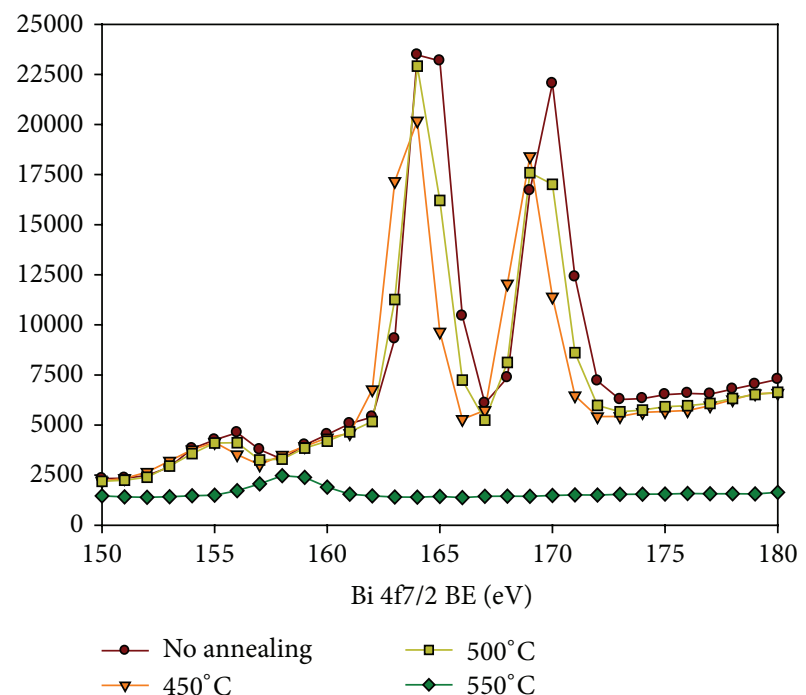

(b)

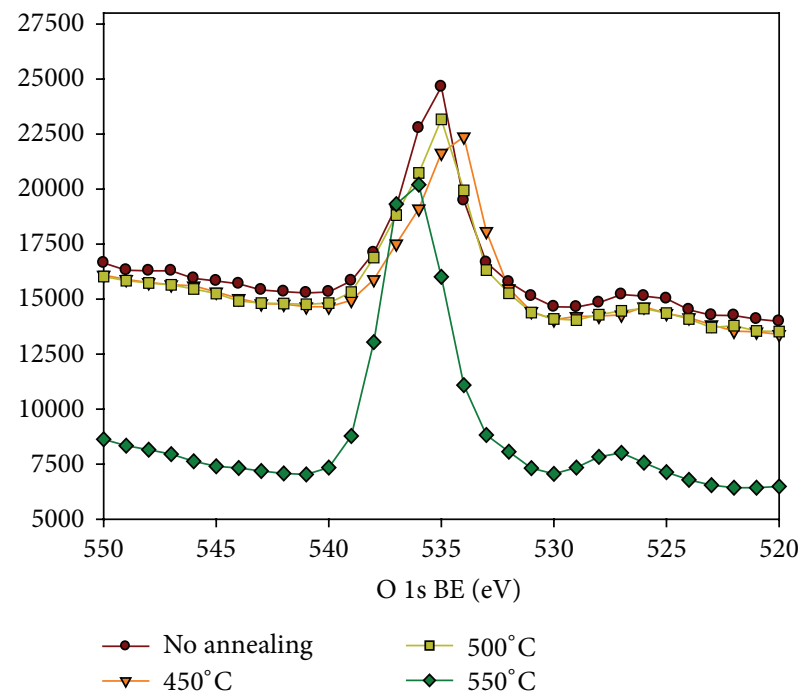

(d)

Figure 4: XPS of the CBTi144 thin films with different annealing temperatures: (a) Ca 2p3/2, (b) Bi 4f7/2, (c) Ti 2p3/2, and (d) O 1s. 


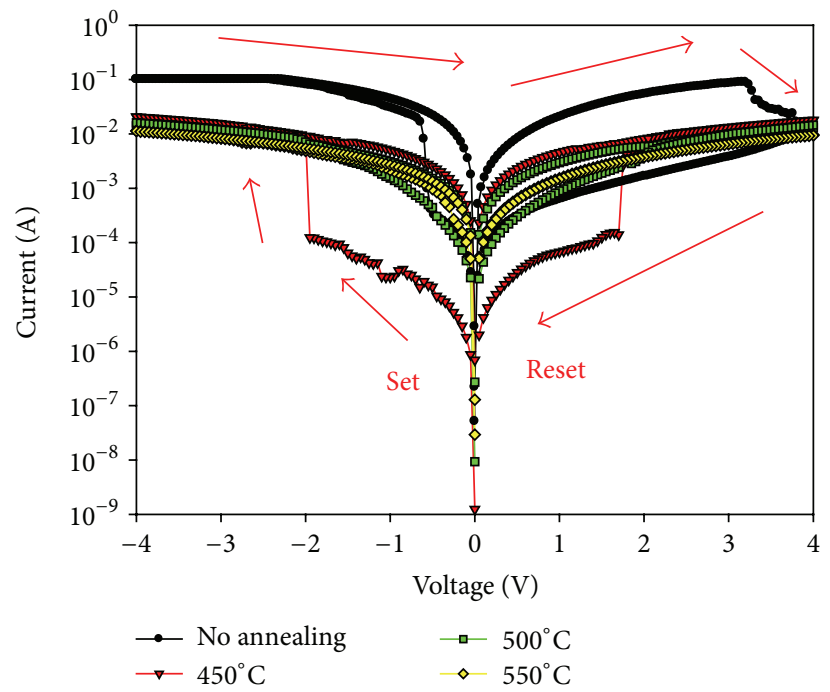

FIGURE 5: $I-V$ characteristics of the CBTil44 RRAM cell without and with $450-550^{\circ} \mathrm{C}$ RTA.
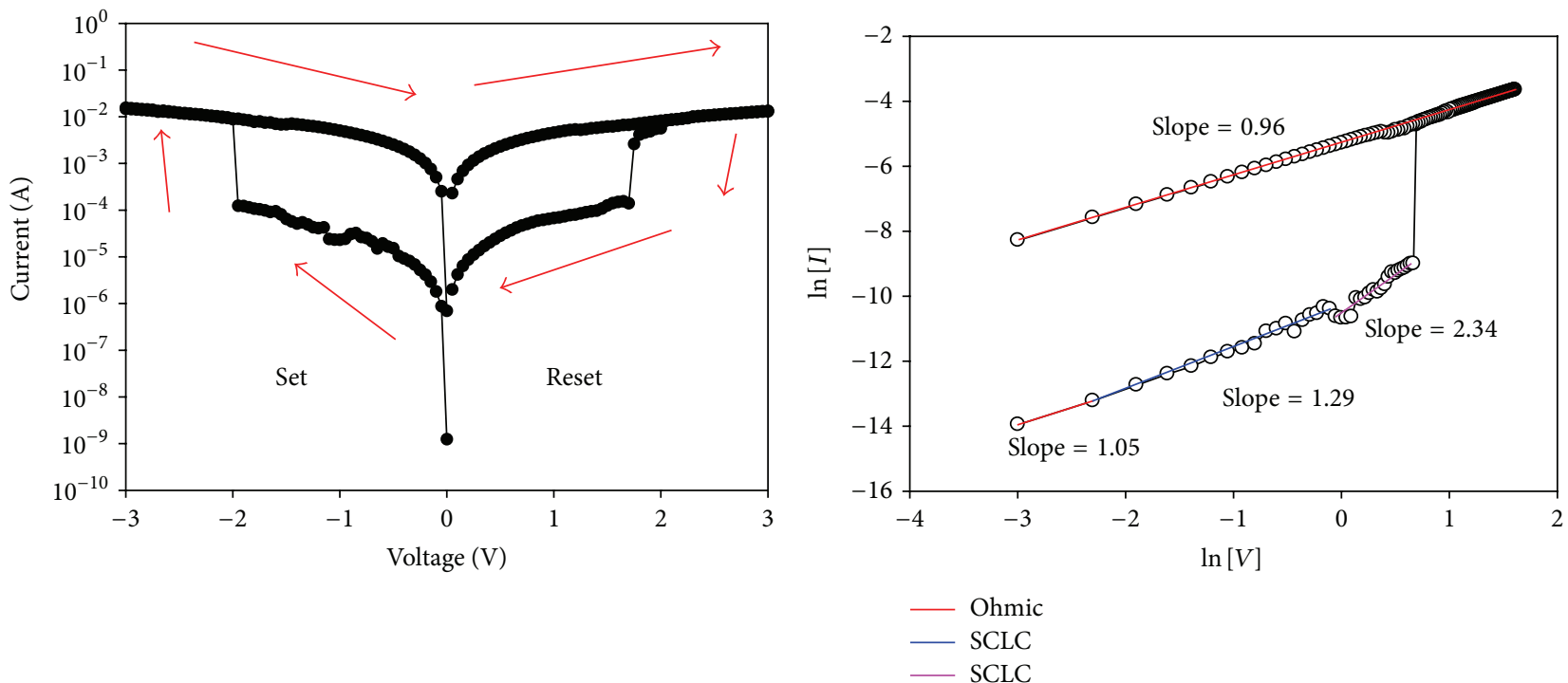

(a)

(b)

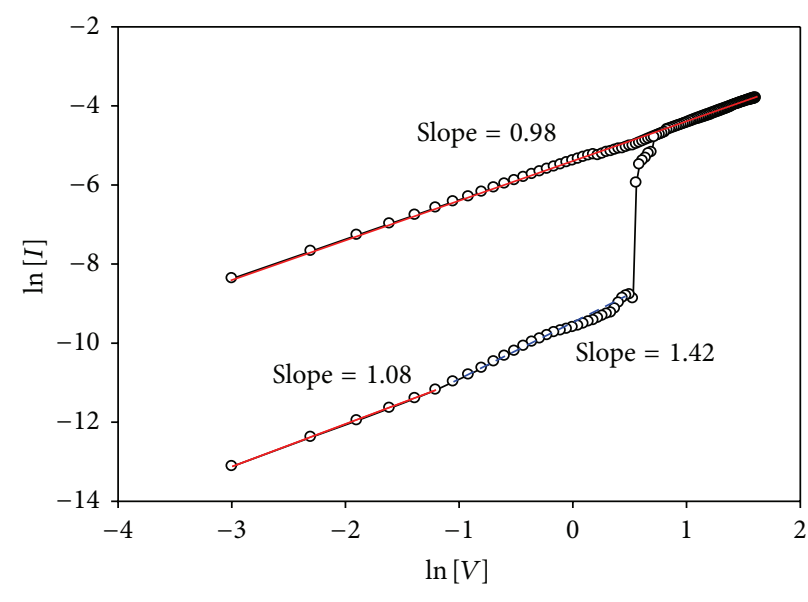

Ohmic

- - SCLC

(c)

Figure 6: Current conduction mechanisms of the Al/CBTil44/ITO/glass RRAM cell annealed at $450^{\circ} \mathrm{C}$ : (a) in the entire switching operation, (b) during the Set process, and (c) during the Reset process. 


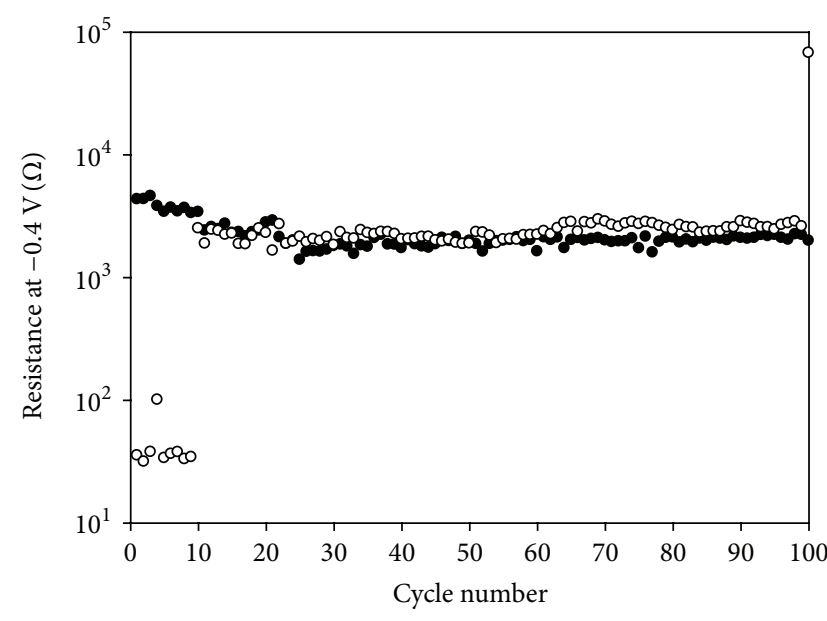

- LRS

○ HRS

(a)

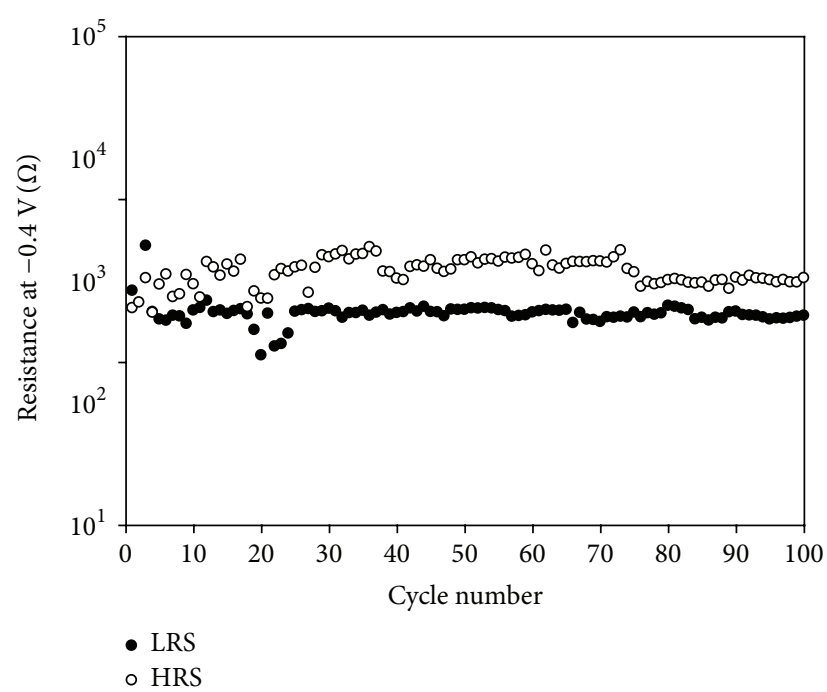

(c)

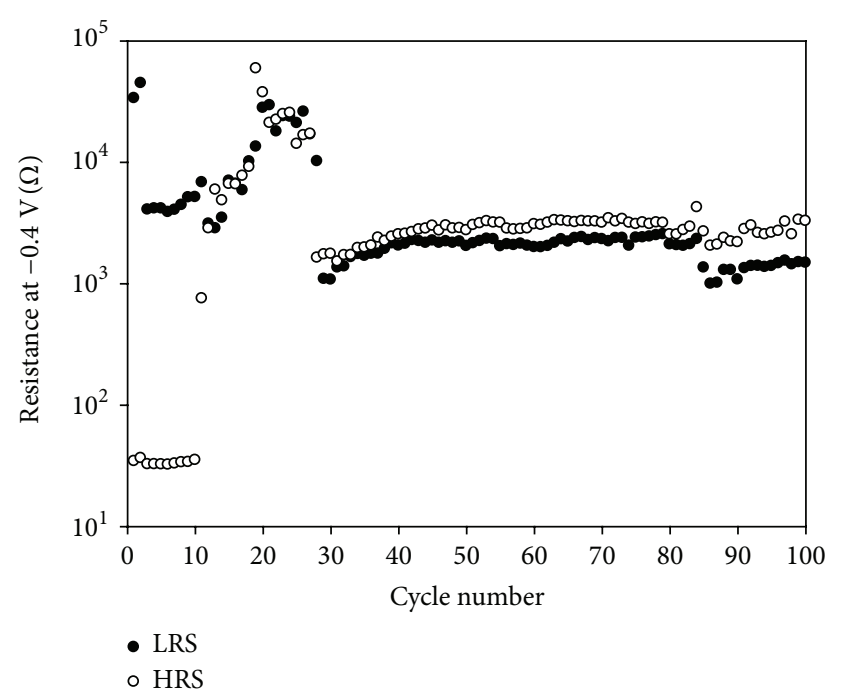

(b)

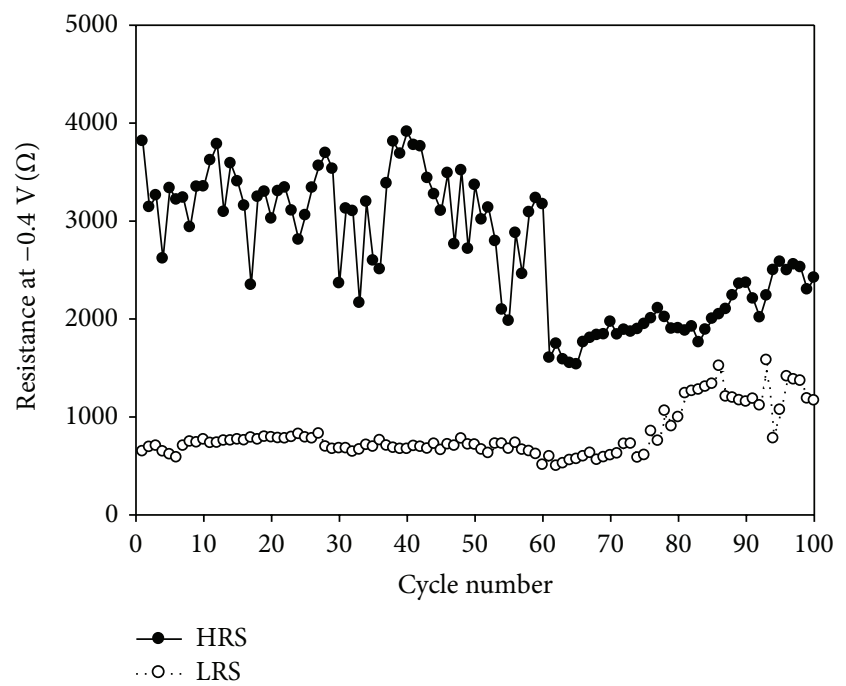

(d)

FIgURE 7: Endurance test of the Al/CBT/ITO/glass cell with different CBT annealing conditions: (a) as-deposited, (b) $450^{\circ} \mathrm{C}$ annealed, (c) $500^{\circ} \mathrm{C}$ annealed, and (d) $550^{\circ} \mathrm{C}$ annealed.

show that the CBT films are of polycrystalline and the peaks of the XRD patterns correspond to the (006), (008), (119), (2010), and (220) orientations of the perovskite crystal [19]. As the annealing is increased, most of the intensities of the XRD peaks increase. This indicates that the grain sizes of the CBT films increase with the RTA temperature.

Figure 4 shows the XPS analysis of the CBTil44 thin films with different annealing conditions. It is noted that the amounts of all the compositional elements in the CBT films decrease as the annealing temperature increases. The oxygen content decreases slightly for the cases of $450^{\circ} \mathrm{C}$ and $500^{\circ} \mathrm{C}$ annealing that the oxygen vacancies may increase accordingly. However, as the annealing temperature increased to $550^{\circ} \mathrm{C}$ which is close to the melting point of the glass substrate, the oxygen content decreases drastically presumably due to the increased stress between the CBT film and the ITO/glass substrate.
Figure 5 shows the current-voltage $(I-V)$ characteristics of the CBTil44 thin films without and with $450-550^{\circ} \mathrm{C}$ RTA. From the $I-V$ measurement, the CBTil44 thin films show good nonvolatile resistive switching properties. The transport current of the CBTil44 thin film increases as the RTA temperature increases up to $450^{\circ} \mathrm{C}$. However, the transport current of the CBTil44 films will decrease if the RTA temperature is increased to $500^{\circ} \mathrm{C}$ and $550^{\circ} \mathrm{C}$. When the annealing temperature increases, the concentration of the oxygen vacancies in the CBTil44 thin film reduces that the bipolar resistive switching characteristics of the CBTil44 RRAM structure will deteriorate.

Figure 6(a) shows the $I-V$ characteristics of the transparent Al/CBTil44/ITO/glass RRAM cell exhibiting bipolar resistive switching behavior with different conduction mechanisms during the switching operation. With RTA temperature of $450^{\circ} \mathrm{C}$, the $I-V$ characteristics of the CBTil44 RRAM 
TABLE 1

\begin{tabular}{lc}
\hline Target diameter $($ inch $)$ & 2 \\
Substrate temperature $\left({ }^{\circ} \mathrm{C}\right)$ & 30 \\
RF power $(\mathrm{W})$ & 100 \\
Chamber pressure (mTorr) & 20 \\
Oxygen concentration $(\%)$ & 0 \\
Deposition time $(\mathrm{h})$ & 2 \\
Annealing temperature $\left({ }^{\circ} \mathrm{C}\right)$ & $450-550$ \\
\hline
\end{tabular}

cell exhibit large on/off ratio over 100 at a bias voltage of $0.1 \mathrm{~V}$. There are two conduction mechanisms, the Ohm's law $(I / V)$ and the trap-filled limit $\left(I / V_{n}\right)$, dominant during the Set process of the RRAM cell, as shown in Figure 6(b). The thermally generated carrier density is higher than the injected carrier density in the low bias regime $[7,8]$. Therefore, the Ohm's law mechanism dominates the conduction behavior in the low bias regime. The SCLC characteristics include the Ohm's law $(I \propto V)$, the trap-filled limit behavior, and the Child's law $\left(I \propto V^{2}\right)[7,8]$. However, the HRS has two kinds of conduction mechanisms in the high bias regime where the trap model with space-charge-limited conduction (SCLC) is dominant [20]. Figure 6(c) shows the current conduction mechanisms during the Reset process of the RRAM cell. In the LRS and HRS, the Reset process has similar conduction mechanisms to the Set process.

Figure 7 shows the endurance characteristics of the $\mathrm{Al} / \mathrm{CBT} / \mathrm{ITO} /$ glass cells with different annealing conditions. For the case of $450^{\circ} \mathrm{C}$ annealing as shown in Figure 7(b), the endurance characteristics of the cell in the first 10 continuous switching cycles still show an HRS/LRS ratio of 100. But after 10 continuous switching cycles, the cell shows an unstable HRS/LRS ratio. For the case of $500^{\circ} \mathrm{C}$ and $550^{\circ} \mathrm{C}$ annealing as shown in Figures $7(\mathrm{c})$ and $7(\mathrm{~d})$, the HRS/LRS ratio is even degraded. It is mainly because of the large reduction in oxygen content at higher annealing temperatures that the cell cannot switch properly in the HRS and LRS.

\section{Conclusions}

In this work, the resistive switching behavior of the transparent Al/CBTil44/ITO/glass RRAM cells has been investigated. Our results show that the conduction switching behavior of the CBTil44 RRAM cells is of bipolar switching. The current conduction mechanisms of the CBTil44 RRAM cells have also been discussed in this work.

\section{Conflict of Interests}

The authors declare that there is no conflict of interests regarding the publication of this paper.

\section{Acknowledgments}

This work was financially supported by the National Science Council of the Republic of China under Contracts NSC1012221-E-224-037 and NSC102-2221-E-224-074. The authors would like to thank the National Nano Device Laboratories for the measurement support.

\section{References}

[1] S.-Y. Wang, C.-H. Tsai, D.-Y. Lee, C.-Y. Lin, C.-C. Lin, and T.-Y. Tseng, "Improved resistive switching properties of $\mathrm{Ti} / \mathrm{ZrO}_{2} / \mathrm{Pt}$ memory devices for RRAM application," Microelectronic Engineering, vol. 88, no. 7, pp. 1628-1632, 2011.

[2] A. Prakash, S. Maikap, C. S. Lai et al., "Bipolar resistive switching memory using bilayer $\mathrm{TaO}_{x} / \mathrm{WO}_{x}$ films," Solid-State Electronics, vol. 77, pp. 35-40, 2012.

[3] L.-M. Chen, T.-Y. Lin, C.-C. Chang, S.-C. Chang, and T.-S. Chin, "Electrode effect on resistive switching of Ti-added amorphous $\mathrm{SiO}_{x}$ films," Thin Solid Films, vol. 518, no. 24, pp. 73527355, 2010.

[4] F.-W. Yang, K.-H. Chen, C.-M. Cheng, and F.-Y. Su, "Bipolar resistive switching properties in transparent vanadium oxide resistive random access memory," Ceramics International, vol. 39, supplement 1, pp. S729-S732, 2013.

[5] A. Sawa, T. Fujii, M. Kawasaki, and Y. Tokura, "Hysteretic current-voltage characteristics and resistance switching at a rectifying Ti/ $\mathrm{Pr}_{0.7} \mathrm{Ca}_{0.3} \mathrm{MnO}_{3}$ interface," Applied Physics Letters, vol. 85, no. 18, pp. 4073-4075, 2004.

[6] S. Seo, M. J. Lee, D. H. Seo et al., "Reproducible resistance switching in polycrystalline NiO films," Applied Physics Letters, vol. 85, no. 23, pp. 5655-5657, 2004.

[7] F.-C. Chiu, H.-W. Chou, and J. Y.-M. Lee, "Electrical conduction mechanisms of metal/ $\mathrm{La}_{2} \mathrm{O}_{3} / \mathrm{Si}$ structure," Journal of Applied Physics, vol. 97, no. 10, Article ID 103503, pp. 1-5, 2005.

[8] F.-C. Chiu, "Electrical characterization and current transportation in metal/ $\mathrm{Dy}_{2} \mathrm{O}_{3} / \mathrm{Si}$ structure," Journal of Applied Physics, vol. 102, no. 4, Article ID 044116, pp. 1-5, 2007.

[9] F.-C. Chiu, P.-W. Li, and W.-Y. Chang, "Reliability characteristics and conduction mechanisms in resistive switching memory devices using $\mathrm{ZnO}$ thin films," Nanoscale Research Letters, vol. 7, article 178, 2012.

[10] C.-H. Lu and C.-H. Wu, "Preparation, sintering, and ferroelectric properties of layer-structured strontium bismuth titanium oxide ceramics," Journal of the European Ceramic Society, vol. 22, no. 5, pp. 707-714, 2002.

[11] K. H. Chen, C. L. Wu, J. Y. Lin, and C. M. Cheng, "Improvement on oxygen vacancies effect of high dielectric constant $\left(\mathrm{Ba}_{0.7} \mathrm{Sr}_{0.3}\right)\left(\mathrm{Ti}_{0.9} \mathrm{Zr}_{0.1}\right) \mathrm{O}_{3}$ thin films using by plasma treatment," Advanced Materials Research, vol. 239-242, pp. 1002-1005, 2011.

[12] A. V. Murugan, A. B. Gaikwad, V. Samuel, and V. Ravi, "Preparation of nanocrystalline ferroelectric $\mathrm{CaBi}_{4} \mathrm{Ti}_{4} \mathrm{O}_{15}$ by citrate gel method," Ceramics International, vol. 33, no. 4, pp. 569-571, 2007.

[13] A. Z. Simões, C. S. Riccardi, M. A. Ramírez, L. S. Cavalcante, E. Longo, and J. A. Varela, "Synthesis and characterization of $\mathrm{CaBi}_{4} \mathrm{Ti}_{4} \mathrm{O}_{15}$ thin films annealed by microwave and conventional furnaces," Solid State Sciences, vol. 9, no. 8, pp. 756-760, 2007.

[14] R. Z. Hou and X. M. Chen, "Neodymium substituted $\mathrm{CaBi}_{4} \mathrm{Ti}_{4} \mathrm{O}_{15}$ bismuth layered compound," Journal of the European Ceramic Society, vol. 26, no. 8, pp. 1379-1383, 2006.

[15] X. Zheng, X. Huang, and C. Gao, "Study on ferroelectric and dielectric properties of La-doped $\mathrm{CaBi}_{4} \mathrm{Ti}_{4} \mathrm{O}_{15}$-based ceramics," Journal of Rare Earths, vol. 25, no. 2, pp. 168-172, 2007. 
[16] A. Z. Simoes, M. A. Ramírez, A. Ries, J. A. Varela, E. Longo, and R. Ramesh, "Electromechanical properties of calcium bismuth titanate films: a potential candidate for lead-free thin-film piezoelectrics," Applied Physics Letters, vol. 88, no. 7, Article ID 072916, pp. 1-3, 2006.

[17] K. Kato, D. Fu, K. Suzuki, K. Tanaka, K. Nishizawa, and T. Miki, "Ferro-and piezoelectric properties of polar-axis-oriented $\mathrm{CaBi}_{4} \mathrm{Ti}_{4} \mathrm{O}_{15}$ films," Applied Physics Letters, vol. 84, no. 19, pp. 3771-3773, 2004.

[18] T. F. Chien, J. H. Tsai, K. H. Chen, C. M. Cheng, and C. L. Wu, "The ferroelectric and electrical properties of $\mathrm{CaBi}_{4} \mathrm{Ti}_{4} \mathrm{O}_{15}$ thin films prepared by sol-gel technology," Advanced Materials Research, vol. 239-242, pp. 891-894, 2011.

[19] K. Kato, K. Suzuki, K. Nishizawa, and T. Miki, "Ferroelectric properties of alkoxy-derived $\mathrm{CaBi}_{4} \mathrm{Ti}_{4} \mathrm{O}_{15}$ thin films on Ptpassivated Si," Applied Physics Letters, vol. 78, no. 8, pp. 1119-1121, 2001.

[20] J. Y. Lin and B. X. Wang, "Resistive switching in conductivebridging random-access memory structure with nanocrystalline silicon films," Japanese Journal of Applied Physics, vol. 52, no. 4, Article ID 044002, pp. 1-5, 2013. 

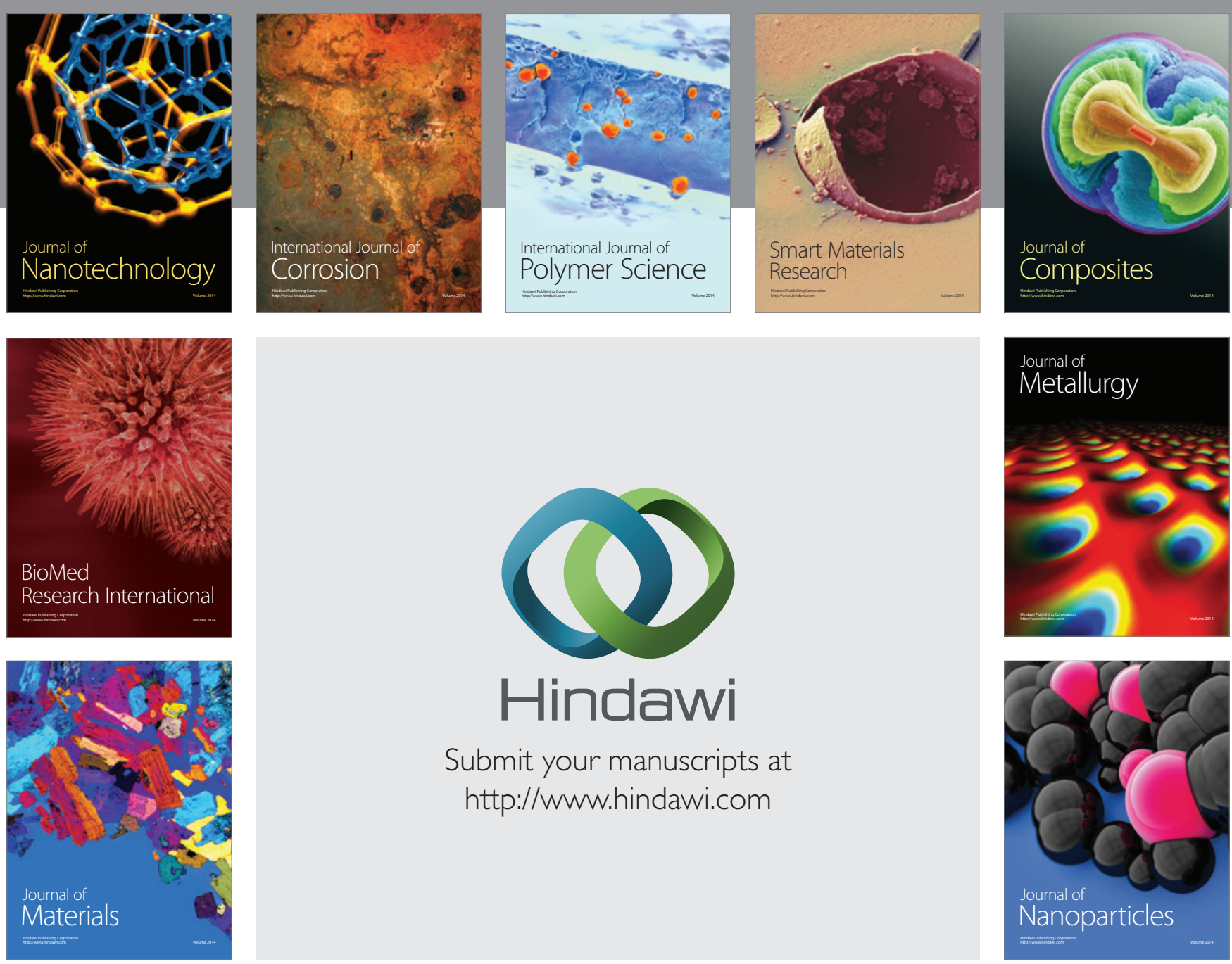

Submit your manuscripts at http://www.hindawi.com
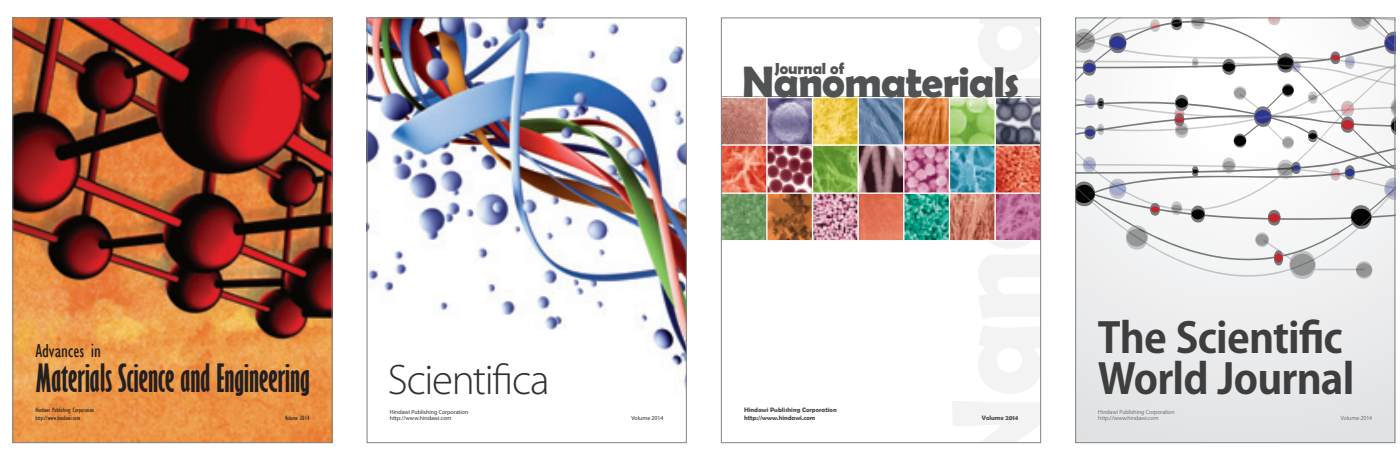

\section{The Scientific World Journal}
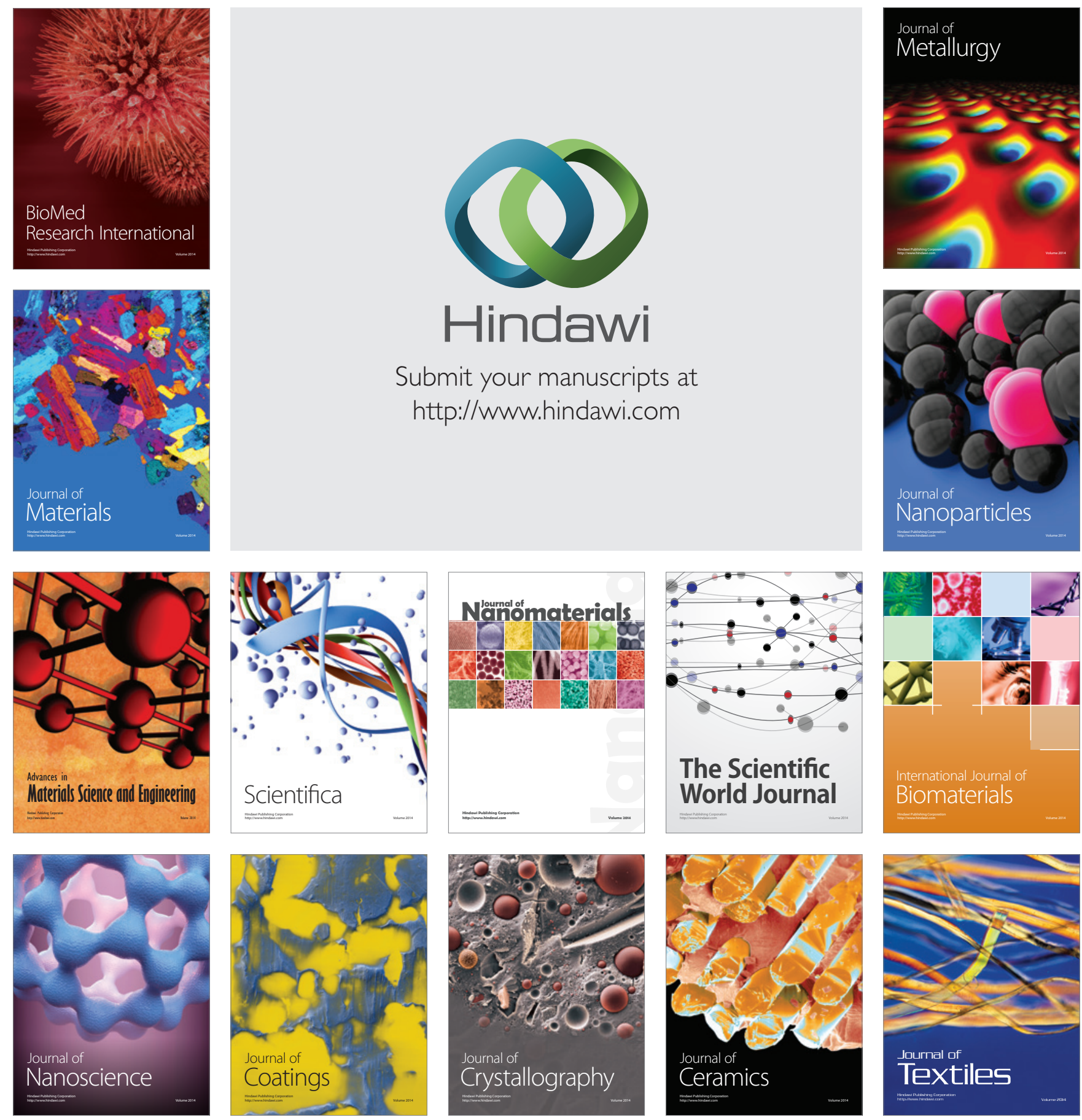